\title{
Prognostic impact of Epstein-Barr Virus (EBV)-DNA copy number at diagnosis in chronic lymphocytic leukemia
}

\author{
Jin-Hua Liang ${ }^{1, *}$, Rui Gao ${ }^{2,}{ }^{*}$, Yi Xia ${ }^{1}$, Robert Peter Gale ${ }^{3}$, Rui-Ze Chen ${ }^{1}$, Yu-Qiong \\ Yang $^{1}$, Li Wang ${ }^{1}$, Xiao-Yan Qu ${ }^{1}$, Hai-Rong Qiu ${ }^{1}$, Lei Cao ${ }^{1}$, Min Hong ${ }^{1}$, Rong Wang ${ }^{1}$, \\ Yan Wang ${ }^{1}$, Lei Fan ${ }^{1}$, Yao-Yu Chen ${ }^{1}$, Zhi-Bin Hu${ }^{4}$, Jian-Yong $\mathbf{L i}^{1,5}$ and Wei Xu${ }^{1}$ \\ ${ }^{1}$ Department of Hematology, The First Affiliated Hospital of Nanjing Medical University, Jiangsu Province Hospital, Nanjing, \\ China \\ ${ }^{2}$ Nanjing Medical University, Nanjing, China \\ ${ }^{3}$ Haematology Research Centre, Division of Experimental Medicine, Department of Medicine, Imperial College London, \\ London, United Kingdom \\ ${ }^{4}$ Department of Epidemiology and Biostatistics, Nanjing Medical University, School of Public Health, Nanjing, China \\ ${ }^{5}$ Collaborative Innovation Center for Cancer Personalized Medicine, Nanjing Medical University, Nanjing, China \\ * These authors have contributed equally to this work \\ Correspondence to: Wei $X u$, email: xuwei10000@hotmail.com
}

Jian-Yong Li, email: lijianyonglm@medmail.com.cn

Keywords: chronic lymphocytic leukemia; Epstein-Barr virus; prognosis

Received: July 26, $2015 \quad$ Accepted: October 09, $2015 \quad$ Published: November 02, 2015

This is an open-access article distributed under the terms of the Creative Commons Attribution License, which permits unrestricted use, distribution, and reproduction in any medium, provided the original author and source are credited.

\section{ABSTRACT}

Epstein-Barr virus (EBV)-DNA is detected in the blood of some persons with chronic lymphocytic leukemia (CLL) at diagnosis. Whether this is important in the development or progression of CLL is controversial. We interrogated associations between blood EBV-DNA copy number and biological and clinical variables in 243 new-diagnosed consecutive subjects with CLL. Quantification of EBV-DNA copies was done by real-time quantitative PCR (RQ-PCR). All subjects had serological evidence of prior EBV-infection. However, only 24 subjects (10\%) had a EBV-DNA-positive test at diagnosis. EBV-DNA-positive subjects at diagnosis had lower hemoglobin concentrations and platelet levels, higher thymidine kinase-1 and serum ferritin levels, un-mutated IGHV genes and a greater risk of Richter transformation compared with EBV-DNA-negative subjects. Percent CD20-, CD148- and ZAP70-positive cells and mean fluorescence intensity (MFI) of each cluster designation were also increased in EBV-DNA-positive subjects at diagnosis. EBV-DNA test positivity was associated with a briefer time-to-treatment interval (HR 1.85; [95\% confidence interval, 1.13, 3.03]; $P=0.014$ ) and worse survival (HR 2.77; $[1.18,6.49] ; P=0.019$ ). Reduction in EBV copies was significantly associated with therapy-response. A positive blood EBV-DNA test at diagnosis and sequential testing of EBV copies during therapy were significantly associated with biological and clinical variables, time-to-treatment, therapy-response and survival. If validated these data may be added to CLL prognostic scoring systems.

\section{INTRODUCTION}

EBV-infection is associated with several lymphomas such as Hodgkin lymphoma, Burkitt lymphoma, some T/NK-cell lymphomas and posttransplant lymphoproliferative disorders [1-3]. EBV can be detected in neoplastic B-cells in some persons with chronic lymphocytic leukemia (CLL) [4-8], especially those with Richter transformation [9-11]. However, associations between EBV-infection and CLL are controversial and an etiological role in CLL is still unproved [7-10]. Specifically, it is unclear if EBV-activation plays a role in 
Table 1: Clinical and biological variables in EBV-DNA-positive and -negative subjects

\begin{tabular}{|c|c|c|c|c|c|c|c|}
\hline $\begin{array}{l}\text { Clinical } \\
\text { characteristics }\end{array}$ & $\begin{array}{c}\text { EBV-DNA-positi } \\
\text { ve }\end{array}$ & $\begin{array}{c}\text { EBV-DNA-neg } \\
\text { ative }\end{array}$ & P-value & $\begin{array}{c}\text { Biological } \\
\text { characteristics }\end{array}$ & $\begin{array}{c}\text { EBV-DNA-p } \\
\text { ositive }\end{array}$ & $\begin{array}{c}\text { EBV-DNA-negat } \\
\text { ive }\end{array}$ & P-value \\
\hline Age $>60 y$ & $12 / 24$ & $100 / 219$ & 0.83 & TP53 disruption & $4 / 22$ & $39 / 200$ & 1.00 \\
\hline Sex (Male) & $18 / 24$ & $151 / 219$ & 0.65 & IGHV un-mutated & $15 / 24$ & $70 / 219$ & $<0.01$ \\
\hline Rai $\geq$ stage-2 & $13 / 24$ & $109 / 219$ & 0.83 & Richter transformation & $3 / 24$ & $5 / 219$ & 0.03 \\
\hline Binet $\geq$ stage- $B$ & $11 / 24$ & $127 / 219$ & 0.28 & - & - & - & - \\
\hline ALC $>50 \times 10 E+9 / L$ & $4 / 24$ & $60 / 219$ & 0.33 & - & - & - & - \\
\hline PLT $<100 \times 10 E+9 / L$ & $10 / 24$ & $49 / 219$ & 0.04 & - & - & - & - \\
\hline $\mathrm{HB}<100 \mathrm{~g} / \mathrm{L}$ & $10 / 24$ & $42 / 219$ & 0.02 & - & - & - & \\
\hline SF $>$ ULN & $8 / 24$ & $30 / 219$ & 0.03 & - & - & - & - \\
\hline ALB $<40 \mathrm{~g} / \mathrm{L}$ & $10 / 24$ & $87 / 219$ & 1.00 & - & - & - & - \\
\hline TK-1 >ULN & $12 / 24$ & $39 / 219$ & $<0.01$ & - & - & - & - \\
\hline $\mathrm{LDH}>\mathrm{ULN}$ & $8 / 24$ & $56 / 219$ & 0.47 & - & - & - & - \\
\hline$\beta 2-M G>U L N$ & $20 / 24$ & $151 / 219$ & 0.17 & - & - & - & - \\
\hline
\end{tabular}

Abbreviations: ALB: albumin; ALC: absolute lymphocytic counts; $\beta 2-M G$ : $\beta 2-$ microglobulin; HB: hemoglobine; IGHV: immunoglobulin heavy-chain variable region; LDH: lactate dehydrogenase; PLT: platelet; SF: serum ferritin; TK-1: thymidine kinase-1; ULN: upper limits of normal.

causing CLL, whether the immune suppression intrinsic to CLL results in activation of latent $\mathrm{EBV}$-infection, both or neither.

Studies of EBV-infection, typically re-activation of latent infection, in persons with CLL initially analyzed anti-EBV antibodies [12]. However, this approach is complex and unreliable because persons with CLL have impaired immunity and defective antibody responses to infections such as Diplococcus pneumonia, Herpes viruses like Varicella-zoster virus (VZV) and EBV [13, 14]. Recent studies directly quantify EBV-infection by measuring blood EBV-DNA [15]. Different compartments have been sampled using real-time quantitative polymerase chain reaction (RQ-PCR) including plasma, serum, mononuclear cells or whole blood [16]. EBV-DNA detected in these compartments by RT-PCR is associated with prognosis in several EBV-related lymphomas [1722]. However, there are few if any similar studies in persons with CLL.

\section{RESULTS}

\section{Subjects}

Twenty four subjects (10\%) had a positive EBVDNA test at diagnosis. Median viral concentration was $6.30 \times 10 \mathrm{E}+4$ copies $/ \mathrm{mL}$ (range, $5.20 \times 10 \mathrm{E}+3$ to $3.80 \times 10 \mathrm{E}+5$ copies $/ \mathrm{mL}$ ). Biological and clinical variables are compared between the EBV-DNA-positive and -negative cohorts in Table 1. All subjects had serological evidence of prior EBV-infection (EBNA-IgG-positive, EBV-CA-IgG-positive and/or EBV-CA-IgA-positive). Among the 24 subjects with EBV-DNA-positive, 21 had serological evidence of active EBV-infection (EBV-EAIgG-positive). Significant differences included hemoglobin $<100 \mathrm{~g} / \mathrm{L}(P=0.02)$, platelets $<100 \times 10 \mathrm{E}+9 / \mathrm{L}(P=0.04)$, thymidine kinase-1 $>$ upper limits of normal (ULN; $P<$ $0.01)$, serum ferritin $(P=0.03)$, immunoglobulin heavychain variable region $(I G H V)$ un-mutated $(P<0.01)$ and Richter transformation $(P=0.03)$. Immunophenotypes are compared in Table 2. There was no significant association between EBV-DNA test result and $V H$ family (Supplement Table 1) or $I G H V$ gene usages (Supplement Table 2).
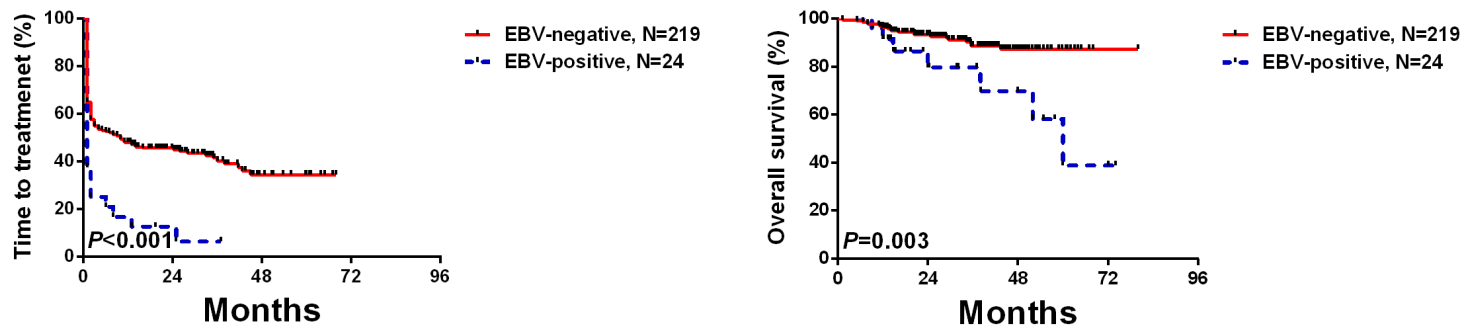

Figure 1: Freedom-from-therapy and survival by EBV-DNA test result at diagnosis. 
Table 2: The comparison of the expressions of the immunophenotypical markers between EBV-DNA-positive and EBV-DNA-negative CLL subjects

\begin{tabular}{|c|c|c|c|c|c|c|c|}
\hline Markers & No. of cases & $\begin{array}{c}\text { EBV-DNA-positive } \\
\text { (mean, \%) }\end{array}$ & $\begin{array}{c}\text { EBV-DNA-negative } \\
\text { (mean, \%) }\end{array}$ & $P$-value & $\begin{array}{c}\text { EBV-DNA-positive } \\
\text { (mean, MFI) }\end{array}$ & $\begin{array}{c}\text { EBV-DNA-negative } \\
\text { (mean, MFI) }\end{array}$ & $P$-value \\
\hline CD19 & 216 & $87 \% \pm 2 \%$ & $80 \% \pm 1 \%$ & 0.029 & $777 \pm 121$ & $758 \pm 70$ & 0.932 \\
\hline CD23 & 216 & $70 \% \pm 4 \%$ & $67 \% \pm 1 \%$ & 0.547 & $286 \pm 59$ & $249 \pm 16$ & 0.463 \\
\hline CD5 & 216 & $80 \% \pm 3 \%$ & $70 \% \pm 1 \%$ & 0.020 & $286 \pm 10$ & $238 \pm 17$ & 0.439 \\
\hline CD20 & 216 & $84 \% \pm 2 \%$ & $75 \% \pm 1 \%$ & 0.022 & $1209 \pm 254$ & $799 \pm 66$ & 0.064 \\
\hline CD22 & 216 & $21 \% \pm 6 \%$ & $20 \% \pm 2 \%$ & 0.833 & $31 \pm 4$ & $27 \pm 4$ & 0.744 \\
\hline CD200 & 214 & $75 \% \pm 5 \%$ & $77 \% \pm 1 \%$ & 0.652 & $248 \pm 46$ & $233 \pm 14$ & 0.741 \\
\hline CD148 & 214 & $78 \% \pm 5 \%$ & $71 \% \pm 1 \%$ & 0.073 & $280 \pm 45$ & $197 \pm 14$ & 0.075 \\
\hline CD38 & 210 & $20 \% \pm 5 \%$ & $17 \% \pm 2 \%$ & 0.557 & $105 \pm 76$ & $36 \pm 7$ & 0.037 \\
\hline ZAP70 & 210 & $31 \% \pm 3 \%$ & $21 \% \pm 1 \%$ & 0.024 & $69 \pm 26$ & $32 \pm 6$ & 0.018 \\
\hline
\end{tabular}

\section{Impact of EBV-DNA testing and clinical outcomes}

Median TTT was 6 months (range, 1-71 months). Median survival was 74 months (range, 2-83 months). 3 -year survival was $89 \%$ (95\% confidence interval [CI], $87,91 \%$ ). At two months after diagnosis 18 subjects in the EBV-DNA-positive cohort were treated vs. 93 of 219 subjects $(42 \%$ in the EBV-DNA-negative cohort $(P$ $<0.001$ ). Median survival was 60 months (range, 9-74 months) in the EBV-DNA-positive cohort $v s$. not reached $(P<0.001$; Figure 1) in the EBV-DNA-negative cohort.

Variables significantly associated with TTT interval in univariate analyses were entered into multivariate analyses. Five parameters, Binet $\geq$ stage-B (HR, 1.45; $[1.01,2.09] ; P=0.044)$, lymphocytes $>50 \times 10 \mathrm{E}+9 / \mathrm{L}(\mathrm{HR}$, $1.41[1.12,2.32] ; P=0.010)$, EBV-DNA positivity (HR, $1.85[1.13,3.03] ; P=0.014)$, un-mutated $I G H V$ state (HR, $1.87[1.28,2.71] ; P=0.001)$ and albumin $<40 \mathrm{~g} / \mathrm{L}(\mathrm{HR}$, $1.17[1.09,2.26] ; P=0.015)$ were significantly associated with TTT interval (Table 3). Variables significantly associated with survival in univariate analyses were entered into multivariate analyses. EBV-DNA-positivity (HR, $2.77[1.18,6.49] ; P=0.019)$, TP53 disruption (HR, $1.75[1.04,5.50] ; P=0.040)$ and un-mutated $I G H V$ state (HR, $2.67[1.04,6.88] ; P=0.042)$ were significantly associated with survival (Table 4).

\section{Changes in EBV copies and therapy-response}

Eighteen subjects with an EBV-DNA-positive test at diagnosis had sequential measurements of EBV copies during therapy and follow-up (Figure 2). Seven patients of therapy responders had a significant reduction of EBVDNA copies (Figure 2A). In contrast, 6 subjects failing therapy had a rapid increase in EBV-DNA copy numbers (Figure 2B). Three subjects had increases in EBV-DNA copies when they developed Richter transformation (Figure 2C).

\section{EBV-DNA copy number and WBC}

Because EBV genomes are mostly intra-cellular, we interrogated whether viral load in whole blood was associated with WBC levels. There was no correlation between WBC levels and EBV-DNA-test result (positive: median, $27 \times 10 \mathrm{E}+9 / \mathrm{L} ;$ range, $2-175 \times 10 \mathrm{E}+9 / \mathrm{L}$ vs. negative: median, $25 \times 10 \mathrm{E}+9 / \mathrm{L}$; range, $2-252 \times 10 \mathrm{E}+9 / \mathrm{L} ; P$ $=0.51)$. Also, in the 24 subjects with a positive EBV-DNA test there was no significant association between the EBVDNA copy number and WBC level $(r=0.253, P=0.244)$. Finally, EBV-DNA copy number in $1 \times 10 \mathrm{E}+6$ cells blood mononuclear cells from five EBV-DNA positive subjects varied substantially. These data indicate the association between a positive EBV-DNA test and biological and clinical variables is independent of WBC level.
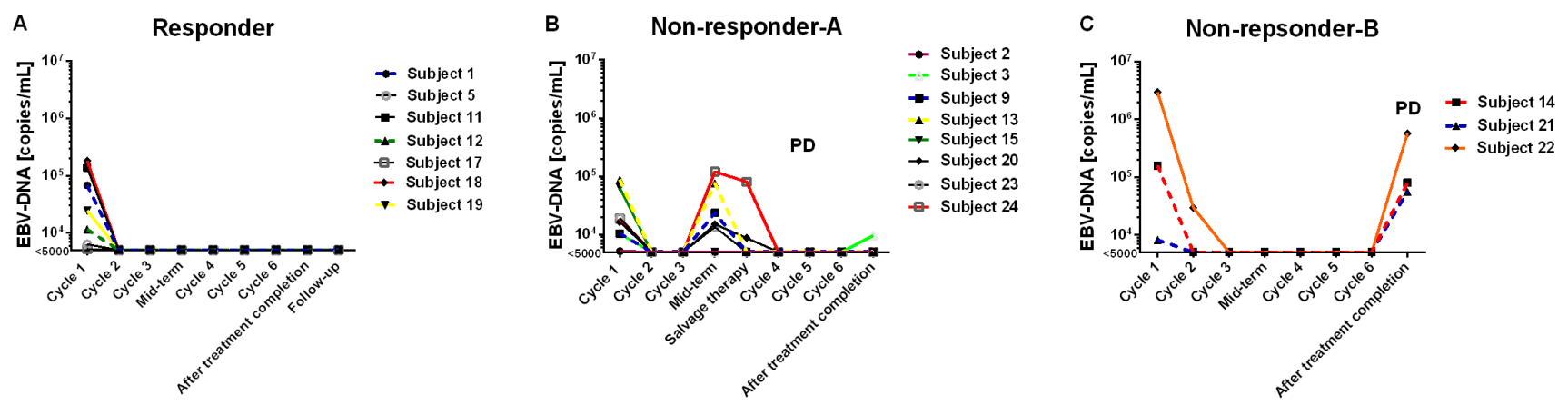

Figure 2: EBV-DNA copies and therapy-response. 
Table 3: Univariate and multivariate Cox regression analysis of TTT for CLL subjects $(N=243)$

\begin{tabular}{|c|c|c|c|c|c|c|}
\hline & \multicolumn{3}{|c|}{ Univariate analysis } & \multicolumn{3}{|c|}{ Multivariate analysis } \\
\hline Characteristics & $\mathrm{HR}$ & $95 \% \mathrm{Cl}$ & $P$-value & $\mathrm{HR}$ & $95 \% \mathrm{Cl}$ & $P$-value \\
\hline Age $>60 y$ & 1.00 & $0.73-1.38$ & 0.985 & - & - & - \\
\hline Sex (male) & 0.99 & $0.70-1.39$ & 0.935 & - & - & - \\
\hline Binet $\geq$ stage- $B$ & 1.53 & $1.01-2.14$ & 0.012 & 1.45 & $1.01-2.09$ & 0.044 \\
\hline$A L C>50 \times 10 E+9 / L$ & 1.52 & $1.18-2.74$ & 0.016 & 1.41 & $1.12-2.32$ & 0.010 \\
\hline ALB $<40 \mathrm{~g} / \mathrm{L}$ & 1.39 & $1.01-1.92$ & 0.043 & 1.17 & $1.09-2.26$ & 0.015 \\
\hline $\mathrm{LDH}>\mathrm{ULN}$ & 1.90 & $1.36-2.67$ & $<0.001$ & 1.28 & $0.87-1.89$ & 0.215 \\
\hline$\beta 2-M G>U L N$ & 1.60 & $1.09-2.33$ & 0.016 & 1.12 & $0.73-1.71$ & 0.615 \\
\hline EBV-DNA positivity & 2.08 & $1.32-3.29$ & 0.002 & 1.85 & $1.13-3.03$ & 0.014 \\
\hline TP53 disruption & 1.64 & $1.12-2.40$ & 0.011 & 1.11 & $0.72-1.71$ & 0.631 \\
\hline IGHV unmutated & 2.15 & $1.55-2.98$ & $<0.001$ & 1.87 & $1.28-2.71$ & 0.001 \\
\hline $\mathrm{PLT}<100 \times 10 \mathrm{E}+9 / \mathrm{L}$ & 1.38 & $0.96-1.98$ & 0.081 & - & - & - \\
\hline $\mathrm{HB}<100 \mathrm{~g} / \mathrm{L}$ & 1.26 & $0.86-1.84$ & 0.231 & - & - & - \\
\hline SF >ULN & 1.18 & $0.78-1.78$ & 0.443 & - & - & - \\
\hline TK-1 >ULN & 1.09 & $0.74-1.61$ & 0.662 & - & - & - \\
\hline CD38 $(\geq 30 \%)$ & 1.26 & $0.88-1.81$ & 0.214 & - & - & - \\
\hline ZAP70 ( $\geq 20 \%)$ & 1.01 & $0.72-1.41$ & 0.969 & - & - & - \\
\hline
\end{tabular}

Abbreviations: ALB: albumin; ALC: absolute lymphocytic counts; $\beta 2-M G$ : $\beta 2$-microglobulin; HB: hemoglobine; IGHV: immunoglobulin heavy-chain variable region; $L D H:$ lactate dehydrogenase; PLT: platelet; SF: serum ferritin; TK-1: thymidine kinase-1; ULN: upper limits of normal.

Table 4: Univariate and multivariate Cox regression analysis of OS for CLL

\begin{tabular}{|c|c|c|c|c|c|c|}
\hline \multirow[b]{2}{*}{ Characteristic } & \multicolumn{3}{|c|}{ Univariate analysis } & \multicolumn{3}{|c|}{ Multivariate analysis } \\
\hline & HR & $95 \% \mathrm{Cl}$ & $P$-value & HR & $95 \% \mathrm{Cl}$ & $P$-value \\
\hline Age $>60 y$ & 2.02 & $0.98-4.16$ & 0.059 & & & \\
\hline Sex (male) & 1.24 & $0.55-2.81$ & 0.603 & & & \\
\hline Binet $\geq$ stage-B & 2.28 & $1.02-5.11$ & 0.045 & 1.33 & $0.54-3.27$ & 0.541 \\
\hline$A L C>50 \times 10 E+9 / L$ & 1.02 & $0.45-2.31$ & 0.957 & & & \\
\hline ALB $<40 \mathrm{~g} / \mathrm{L}$ & 1.64 & $0.79-3.44$ & 0.188 & & & \\
\hline $\mathrm{LDH}>\mathrm{ULN}$ & 3.19 & $1.55-6.56$ & 0.002 & 1.75 & $0.74-4.12$ & 0.199 \\
\hline$\beta 2-M G>U L N$ & 1.75 & $0.72-4.28$ & 0.220 & & & \\
\hline EBV-DNA positivity & 5.20 & $2.43-11.12$ & $<0.001$ & 2.77 & $1.18-6.49$ & 0.019 \\
\hline TP53 disruption & 4.06 & $1.95-8.47$ & $<0.001$ & 1.75 & $1.04-5.50$ & 0.040 \\
\hline IGHV unmutated & 5.06 & $2.32-11.01$ & $<0.001$ & 2.67 & $1.04-6.88$ & 0.042 \\
\hline $\mathrm{PLT}<100 \times 10 \mathrm{E}+9 / \mathrm{L}$ & 1.13 & $0.52-2.46$ & 0.768 & - & - & - \\
\hline $\mathrm{HB}<100 \mathrm{~g} / \mathrm{L}$ & 1.28 & $0.59-2.80$ & 0.536 & - & - & - \\
\hline SF $>$ ULN & 2.04 & $0.94-4.45$ & 0.073 & - & - & - \\
\hline TK-1 >ULN & 1.74 & $0.82-3.73$ & 0.152 & - & - & - \\
\hline CD38 ( $\geq 30 \%)$ & 2.30 & $1.11-4.74$ & 0.023 & 1.61 & $0.73-3.55$ & 0.237 \\
\hline ZAP70 $(\geq 20 \%)$ & 1.28 & $0.60-2.73$ & 0.518 & - & - & - \\
\hline
\end{tabular}

Abbreviations: ALB: albumin; ALC: absolute lymphocytic counts; $\beta 2-M G$ : $\beta 2$-microglobulin; $\mathrm{HB}$ : hemoglobine; IGHV: immunoglobulin heavy-chain variable region; $\mathrm{LDH}$ : lactate dehydrogenase; PLT: platelet; SF: serum ferritin; TK-1: thymidine kinase-1; ULN: upper limits of normal. 


\section{DISCUSSION}

A positive EBV-DNA test at diagnosis was significantly associated with several clinical and biological variables previously reported to correlate with a poor prognosis in persons with CLL. However, the adverse impact of a positive EBV-DNA test persisted as an independent predictor of TTT and survival in multivariate analyses. These data suggest an important role for EBVinfection and/or reactivation in some persons with CLL.

The $10 \%$ incidence of EBV-DNA we detected in whole blood at diagnosis is similar to $14 \%$ reported using a EBV-encoded latent membrane protein 1 (EBV LMP1) mRNA transcript test reported by Tarrand JJ et al. [6] but less than the $38 \%$ detected by in situ hybridization for EBV-encoded small RNA1 (EBV-EBER1) reported by Tsimberidou AM et al. [4]. This difference is likely because EBER-1 is can be detected in latent EBVinfection whereas EBV-DNA and EBV-LMP1 mRNA are found only during active infection [4]. The different test sensitivities of FISH and RT-PCR might be also the reason for the difference. The associations we report between a positive EBV-DNA blood test and worse outcomes are similar to those reported using a test for EBV-EBER1 and of LMP1 mRNA [4, 6, 10]. EBV-infection stimulates proliferation of B-cells and inhibits apoptosis. Changes in immunophenotype are consistent with this notion and suggest EBV-infection, re-activation and/or -replication may be important in the biological and clinical features of CLL in some persons.

Presence of EBV-EBER1 and EBV-LMP-1 mRNA in persons with CLL are associated with briefer TTT, increased risk of Richter transformation and worse survival in several studies [4, 10, 23, 24]. We also found EBV-DNA-positive subjects were also more likely to have Richter transformation. Three subjects who were EBVDNA-positive at diagnosis and who became -negative with therapy had an increase in EBV copy numbers at the time of Richter transformation. These data suggest an association between EBV-infection, re-activation and/or -replication and Richter transformation.

The explanation for the association between EBV-DNA and-infection and/or re-activation and Richter transformation is complex. EBV-infection and/ or reactivation might cause Richter transformation as it does Burkitt lymphoma. Alternatively, development of Richter syndrome might activate EBV-infection. These interactions are not mutually-exclusive and one, both or neither might operate in different persons.

Similar to the study reported by Visco C et al. [25], the etiological role of EBV in CLL cannot be defined in the present study. However, there are several potential explanations of why patients with high EBV DNA loads had poorer outcomes. First, EBV replication causes severe immune suppression. Consequently, persons with a high EBV-DNA load are at increased infection-risk and may have been less able to tolerate anti-CLL therapy. Second, Terrin L et al. [26] reported latently-EBV-infected B-cells induced sustained telomerase which was associated with an aggressive clinical behavior [27]. Third, we observed an association between high EBV-DNA load and unmutated $I G H V$ which was independently-associated with poorer survivals.

Our data indicate an association between blood EBV-DNA test positivity, EBV copy numbers and therapy-response. Because we did not give specific anti-EBV therapy, because drugs used to treat CLL lack anti-EBV activity and because we found no correlation between WBC level and EBV-DNA copy number, we assume this association reflects a biological property of the CLL cells, the host or both. Similar associations are reported in subjects with Hodgkin lymphoma, extra-nodal NK/T-cell lymphoma, diffuse large B-cell lymphoma and nasopharyngeal carcinoma [14, 20-22, 28-31]. These data are consistent with a correlation between EBV-DNA copy levels and disease activity and, if validated, could be used to predict outcomes.

\section{MATERIALS AND METHODS}

\section{Subjects}

Two hundred and forty-three newly diagnosed CLL persons were enrolled in this study from February 2008 to January 2014. Diagnosis of CLL was based on criteria of the International Workshop on CLL-National Cancer Institute (IWCLL-NCI) [32, 33]. The study was approved by the Ethics Committee of the First Affiliated Hospital of Nanjing Medical University. Subjects provided written informed consent and carried out according to the Declaration of Helsinki.

Baseline clinical and biological variables tested are summarized in Table 1. Anti-EBV antibody tests (EBNA-IgG，EBV-CA-IgG，EBV-CA-IgA，EBV-CA$\operatorname{IgM}$ and EBV-EA-IgG) were done in all subjects. immunophenotype analyses included CD5, CD19, CD23, CD20, CD22, CD148, CD200, CD38 and ZAP70 measured by flow cytometry (Table 2). Results for each cluster designation and ZAP70 were expressed as percent positive cells and as mean fluorescence intensity (MFI). Methods and cut-off values are previously reported [3436].

Subjects received therapy according to recommended guidelines $[32,33]$. One hundred and fifty-one subjects $(62 \%)$ received induction therapy with fludarabine, cyclophosphamide and rituximab $(N=69$; $46 \%$, fludarabine and cyclophosphamide $(N=47 ; 31 \%)$, bendamustine $(N=21 ; 14 \%)$ and chlorambucil $(N=14$; 9\%). Physicians were blinded to results of EBV-DNA tests when selecting therapy. 


\section{EBV-DNA by real-time PCR}

Whole blood samples were collected in an EDTAcontaining tube and DNA extracted with the EBVPCR Fluorescence Quantitative Diagnostic Kit (Da An Gene Co., Guangzhou, China). Quantification of EBVspecific sequences was performed by RQ-PCR assay with an ABI PRISM 7500 (Applied Biosystems, Foster City, CA, USA). Copy number was calculated from a standard curve. The lower boundary of test sensitivity was $5 \times 10 \mathrm{E}+3$ copies $/ \mathrm{mL}$ [22]. Subjects with values $<$ $5 \times 10 \mathrm{E}+3$ copies $/ \mathrm{mL}$ were scored as EBV-DNA-negative including potentially subjects with no copies and subjects with values of 1 to $<5 \times 10 \mathrm{E}+3$ copies $/ \mathrm{mL}$.

\section{Statistics}

Fisher exact test was applied to categorical variables and the Mann-Whitney $\mathrm{U}$ test to continuous variables. Time-to-treatment (TTT) interval was defined as interval from diagnosis to first treatment. Survival was defined as interval from diagnosis to death, loss to follow-up or May, 2015. Survival curves were constructed by Kaplan-Meier method, and log-rank test used to test for significant differences. Associations between variables and EBV-DNA testing results were interrogated in univariate analyses. Variables with significant associations were included in multivariate Cox proportional hazards regression analyses. Statistical analyses were performed using SPSS software for Windows (version, 17.0). $P$-values $<0.05$ were considered significant. Data were analyzed as of 1-Jan-2015. Median follow-up is 41 months (range, 14-83 months).

\section{ACKNOWLEDGMENTS}

Supported by National Natural Science Foundation of China (30971296, 81170485, 81170488, 81370657, 81470328), Key Projects of Health Department of Jiangsu Province (K201108), Jiangsu Province's Medical Elite Program (RC2011169), National Public Health Grand Research Foundation (201202017), Project Funded by the Priority Academic Program Development of Jiangsu Higher Education Institute (JX10231801), Program for Development of Innovative Research Teams in the First Affiliated Hospital of Nanjing Medical University, Project of National Key Clinical Specialty. National Science \& Technology Pillar Program (2014BAI09B12), and Project funded by Jiangsu Provincial Special Program of Medical Science (BL2014086). RPG acknowledges support from the National Institute of Health Research (NIHR) Biomedical Research Centre funding scheme. Prof. Nicholas Chiorazzi kindly reviewed the typescript.

\section{CONFLICTS OF INTEREST}

None.

\section{REFERENCES}

1. Thorley-Lawson DA. Epstein-Barr virus: exploiting the immune system. Nat Rev Immunol. 2001; 1:75-82.

2. Timms JM, Bell A, Flavell JR, Murray PG, Rickinson AB, Traverse-Glehen A, Berger F, Delecluse HJ. Target cells of Epstein-Barr-virus (EBV)-positive post-transplant lymphoproliferative disease: similarities to EBV-positive Hodgkin's lymphoma. Lancet. 2003; 361:217-223.

3. Siu LL, Chan JK, Kwong YL. Natural killer cell malignancies: clinicopathologic and molecular features. Histol Histopathol. 2002; 17:539-554.

4. Tsimberidou AM, Keating MJ, Bueso-Ramos CE, Kurzrock R. Epstein-Barr virus in patients with chronic lymphocytic leukemia: a pilot study. Leuk Lymphoma. 2006; 47: 827836.

5. Bueso-Ramos CE, Ferrajoli A, Medeiros LJ, Keating MJ, Estrov Z. Aberrant morphology, proliferation, and apoptosis of B-cell chronicl lymphocytic leukemia cells. Hematology. 2004; 9: 279-286.

6. Tarrand JJ, Keating MJ, Tsimberidou AM, O'Brien S, LaSala RP, Han XY, Bueso-Ramos CE. Epstein-Barr Virus Latent Membrane Protein 1 mRNA Is Expressed in a Significant Proportion of Patients with chronic lymphocytic leukemia. Cancer. 2010; 116:880-887.

7. Teramoto N, Gogolák P, Nagy N, Maeda A, Kvarnung $\mathrm{K}$, Björkholm T, Klein E. Epstein-Barr virus-infected B-chronic lymphocytic leukemia cells express the virally encoded nuclear proteins but they do not enter the cell cycle. J Hum Virol. 2000; 3:125-136.

8. Dolcetti R, Carbone A. Epstein-Barr virus infection and chronic lymphocytic leukemia: a possible progression factor? Infect Agent Cancer. 2010; 5:22.

9. Tsimberidou AM, Keating MJ. Richter's transformation in chronic lymphocytic leukemia. Semin Oncol. 2006; 33:250256.

10. Ansell SM, Li CY, Lloyd RV, Phyliky RL. Epstein-Barr virus infection in Richter's transformation. Am J Hematol. 1999; 60:99-104.

11. Rubin D, Hudnall SD, Aisenberg A, Jacobson JO, Harris NL. Richter's transformation of chronic lymphocytic leukemia with Hodgkin's-like cells is associated with Epstein-Barr virus infection. Mod Pathol.1994; 7:91-98.

12. Lehtinen $\mathrm{T}$, Lumio J, Dillner J, Hakama M, Knekt P, Lehtinen M, Teppo L, Leinikki P. Increased risk of malignant lymphoma indicated by elevated EpsteinBarr virus antibodies-a prospective study. Cancer Causes Control. 1993; 4:187-193.

13. Pasiarski M, Rolinski J, Grywalska E, Stelmach-Goldys A, Korona-Glowniak I, Gozdz S, Hus I, Malm A. Antibody 
and plasmablast response to 13-valent pneumococcal conjugate vaccine in chronic lymphocytic leukemia patients-preliminary report. PloS One. 2014; 9: e114966.

14. Hartkamp A, Mulder AH, Rijkers GT, van Velzen-Blad $\mathrm{H}$, Biesma DH. Antibody response to pneumococcal and haemophilus vaccinations in patients with B-cell chronic lymphocytic leukemia. Vaccine. 2001; 19:1671-1677.

15. Swerdlow SH, Campo E, Harris NL, Jaffe ES, Pileri SA, Stein H, Thiele J, Vardiman JW. WHO Classification of Tumours of Haematopoietic and Lymphoid Tissue. International Agency for Research on Cancer 2008.

16. Takahashi E, Ohshima K, Kimura H, Hara K, Suzuki R, Kawa K, Eimoto T, Nakamura S; NK-cell Tumor Study Group. Clinicopathological analysis of the age-related differences in patients with Epstein-Barr virus (EBV)associated extranasal natural killer (NK)/T-cell lymphoma with reference to the relationship with aggressive NK cell leukaemia and chronic active EBV infection-associated lymphoproliferative disorders. Histopathology. 2011; 59:660-671.

17. Suzuki R, Yamaguchi M, Izutsu K, Yamamoto G, Takada $\mathrm{K}$, Harabuchi $\mathrm{Y}$, Isobe $\mathrm{Y}$, Gomyo $\mathrm{H}$, Koike $\mathrm{T}$, Okamoto M, Hyo R, Suzumiya J, Nakamura S, et al. Prospective measurement of Epstein-Barr virus-DNA in plasma and peripheral blood mononuclear cells of extranodal NK/T-cell lymphoma, nasal type. Blood. 2011; 118:6018-6022.

18. Baldanti F, Grossi P, Furione M, Simoncini L, Sarasini A, Comoli P, Maccario R, Fiocchi R, Gerna G. High levels of Epstein-Barr virus DNA in blood of solid-organ transplant recipients and their value in predicting posttranplant lymphoproliferative disorders. J Clin Microbiol. 2000; 38:613-619.

19. Aalto SM, Juvonen E, Tarkkanen J, Volin L, Haario H, Ruutu T, Hedman K. Epstein-Barr viral load and disease prediction in a large cohort of allogeneic stem cell transplant recipients. Clin Infect Dis. 2007; 45:1305-1309.

20. Ito $Y$, Kimura H, Maeda $Y$, Hashimoto C, Ishida F, Izutsu K, Fukushima N, Isobe Y, Takizawa J, Hasegawa Y, Kobayashi H, Okamura S, Kobayashi H, et al. Pretreatment EBV-DNA copy number is predictive of response and toxicities to SMILE chemotherapy for Extranodal NK/Tcell lymphoma, nasal type. Clin Cancer Res. 2012; 18:41834190.

21. Lei KI, Chan LY, Chan WY, Johnson PJ, Lo YM. Diagnostic and Prognostic Implications of Circulating Cell-free Epstein-Barr Virus DNA in Natural Killer/T-cell lymphoma. Clin Cancer Res. 2002; 8:29-34.

22. Liang JH, Lu TX, Tian T, Wang L, Fan L, Xu J, Zhang R, Gong QX, Zhang ZH, Li JY, Xu W. Epstein-Barr virus (EBV) DNA in whole blood as a superior prognostic and monitoring factor than EBV-encoded small RNA in situ hybridization in diffuse large B-cell lymphoma. Clin Microbiol Infect. 2015; 21:596-602.

23. Lu ZX, Ma XQ, Yang LF, Wang ZL, Zeng L, Li ZJ, Li XN, Tang M, Yi W, Gong JP, Sun LQ, Cao Y. DNAzymes targeted to EBV-encoded latent membrane protein-1 induce apoptosis and enhance radiosensitivity in nasopharyngeal carcinoma. Cancer Lett. 2008; 265:226-238.

24. D'Souza BN, Edelstein LC, Pegman PM, Smith SM, Loughran ST, Clarke A, Mehl A, Rowe M, Gélinas C, Walls D. Nuclear factor kappa B-dependent activation of the antiapoptotic bfl-1 gene by the Epstesin-Barr virus latent membrane protein 1 and activated CD40 receptor. J Virol. 2004; 78:1800-1816.

25. Visco C, Falisi E, Young KH, Pascarella M, Perbellini O, Carli G, Novella E, Rossi D, Giaretta I, Cavallini C, Scupoli MT, De Rossi A, D'Amore ES, et al. EpsteinBarr virus DNA load in chronic lymphocytic leukemia is an independent predictor of clinical course and survival. Oncotarget. 2015; 30:18653-18663. doi: 10.18632/ oncotarget. 4418 .

26. Terrin L, Dal Col J, Rampazzo E, Zancai P, Pedrotti M, Ammirabile G, Bergamin S, Rizzo S, Dolcetti R, De Rossi A. Latent membrane protein 1 of Epstein-Barr virus activates the hTERT promoter and enhances telomerase activity in B lymphocytes. J Virol. 2008; 20:10175-10187.

27. Rampazzo E, Bonaldi L, Trentin L, Visco C, Keppel S, Giunco S, Frezzato F, Facco M, Novella E, Giaretta I, Del Bianco P, Semenzato G, De Rossi A. Telomere length and telomerase levels delineate subgroups of B-cell chronic lymphocytic leukemia with different biological characteristics and clinical outcomes. Haematologica. 2012; 97:56-63.

28. Hohaus S, Santangelo R, Giachelia M, Vannata B, Massini G, Cuccaro A, Martini M, Cesarini V, Cenci T, D’Alo F, Voso MT, Fadda G, Leone G, et al. The viral load of Epstein-Barr virus (EBV) DNA in Peripheral Blood predict for biological and clinical characteristics in Hodgkin lymphoma. Clin Cancer Res. 2011; 17:2885-2892.

29. Kanakry JA, Li H, Gellert LL, Lemas MV, Hsieh WS, Hong F, Tan KL, Gascoyne RD, Gordon LI, Fisher RI, Bartlett NL, Stiff P, Cheson BD, et al. Plasma Epstein-Barr virus DNA predicts outcome in advanced Hodgkin lymphoma: correlative analysis from a large North American cooperative group trial. Blood. 2013; 121:3547-3553.

30. Au WY, Pang A, Choy C, Chim CS, Kwong YL. Quantification of circulating Epstein-Barr virus (EBV) DNA in the diagnosis and monitoring of natural killer cell and EBV-positive lymphoma in immunocompetent patients. Blood. 2004; 104: 243-249.

31. Wang ZY, Liu QF, Wang H, Jin J, Wang WH, Wang SL, Song YW, Liu YP, Fang H, Ren H, Wu RY, Chen B, Zhang $\mathrm{XM}$, et al. Clinical implications of plasma Epstein-Barr virus DNA in early-stage extranodal nasal-type NK/T-cell lymphoma patients receiving primary radiotherapy. Blood. 2012; 120:2003-2010.

32. Cheson BD, Bennett JM, Grever M, Kay N, Keating MJ, O'Brien S, Rai KR. National Cancer Institute-sponsored Working Group guidelines for chronic lymphocytic leukemia: revised guidelines for diagnosis and treatment. 
Blood 1996; 87:4990-4997.

33. Hallek M, Cheson BD, Catovsky D, Caligaris-Cappio F, Dighiero G, Döhner H, Hillmen P, Keating MJ, Montserrat E, Rai KR, Kipps TJ; International Workshopon Chronic Lymphocytic Leukemia. Guidelines for the diagnosis and treatment of chronic lymphocytic leukemia: a report from the International Workshop on Chronic Lymphocytic leukemia updating the National Cancer Institue-Working Group 1996 guidelines. Blood 2008; 111:5446-5456.

34. Xia Y, Fan L, Wang L, Gale RP, Wang M, Tian T, Wu W, Yu L, Chen YY, Xu W, Li JY. Frequencies of SF3B1, NOTCH1, MYD88, BIRC3 and IGHV mutations and TP53 disruptions in Chinese with chronic lymphocytic leukemia: disparities with Europeans. Oncotarget. 2015; 6:5426-5434. doi: 10.18632/oncotarget.3101.

35. Fang C, Zhuang Y, Wang L, Fan L, Wu YJ, Zhang R, Zou ZJ, Zhang LN, Yang S, Xu W, Li JY. High levels of CD20 expression predict good prognosis in chronic lymphocytic leukemia. Cance Sci. 2013; 104:996-1001.

36. Wang YH, Fan L, Wang L, Zhang R, Xu J, Fang C, Li $\mathrm{JY}, \mathrm{Xu}$ W. Efficacy of prophylactic lamivudine to prevent hepatitis B virus reactivation in B-cell lymphoma treated with rituximab-containing chemotherapy. Support Care Cancer. 2013; 21:1265-1271. 